\title{
Factors Influence Financial Inclusion: Evidence from Indonesian Micro Data
}

\author{
Etty Susilowati ${ }^{1}$, Leonnard ${ }^{2}$
}

\begin{abstract}
In order to increase access to formal financial institutions, the Indonesian government has issued various national strategies. However, Indonesia's inclusive financial index is still under other ASEAN countries. Therefore, in this study, we investigate the factors that influence financial inclusion in Indonesia. The microdata from global findex 2014 was carried out in this study by using binary logistic regression analysis. The finding indicates that there is a significant positive relationship between individual characteristics, including financial inclusion, constraints to financial inclusion, utilization of financial services motivation, and loan sources. Since the main targets of financial inclusion are the poor, this finding becomes an essential proposition for policies in the banking sector, that besides the factors of gender, age, education, and type of jobs, income is the primary factor that influences access and utilization of financial services. Mainly regarding loans, increased income will increase the opportunities of the poor to getting loans because only high-income groups have collateral in applying for loans.
\end{abstract}

Keywords: financial inclusion, individual characteristics, saving, loans

JEL Classification: D14, G20

\begin{abstract}
Abstrak. Untuk meningkatkan akses ke lembaga keuangan formal, pemerintah Indonesia mengeluarkan berbagai strategi nasional. Namun, indeks keuangan inklusifIndonesia masih di bawah negara-negara ASEAN lainnya. Oleh karena itu, dalam penelitian ini, kami menyelidiki faktor-faktor yang mempengarubi inklusi keuangan di Indonesia. Data mikro dari global findex 2014 dianalisis dalam penelitian ini dengan menggunakan analisis regresi. Hasil penelitian menunjukkan bahwa terdapat hubungan positif yang signifikan antara karakteristik individu, inklusi keuangan, kendala inklusi keuangan, penggunaan motivasi layanan keuangan, dan sumber kredit. Karena target utama dari inklusi keuangan di Indonesia adalah kelompok masyarakat miskin, maka hasil penelitian ini menjadi masukan yang penting bagi kebijakan di sektor perbankan, bahwa selain faktor-faktor gender, usia, pendidikan, dan jenis pekerjaan, pendapatan menjadi faktor utama yang mempengaruhi keberhasilan inklusi keuangan. Khususnya mengenai kredit, peningkatan pendapatan akan meningkatkan peluang masyarakat untuk mendapatkan pinjaman, karena hanya kelompok berpendapatan lebih tinggi yang memiliki jaminan dalam mengajukan pinjaman.
\end{abstract}

Kata Kunci: Inklusi keuangan; Karakteristik individu; Tabungan; Kredit

\section{How to Cite:}

Susilowati, E., \& Leonnard. (2019). Factors Influence Financial Inclusion: Evidence from Indonesian Micro Data. Etikonomi: Jurnal Ekonomi. Vol. 18 (1): 121 - 132. doi: http//dx.doi.org/10.15408/etk.v18i1.9070. 


\section{Introduction}

The growth of financial institutions with various scales and different services is not expected to be equitably accessed and utilized by all levels of society (Global Partnership for Financial Inclusion, 2011). It realizes that formal financial institutions trust institutions that have stringent regulations in managing their business. Consequently, only a particular group of people or business units that are considered feasible and bankable can access and use the services provided. Meanwhile, community groups or business units that need financial support are still far from the reach of financial institution services (Claessens, 2006). Community groups which are not served by the financial system are called exclusive financial groups as opposed to financial inclusion. This term defines as the proportion of individuals and companies that have access to formal financial institutions (World Bank, 2014). The main targets of inclusive finance are the poor, the productive poor, migrant workers and remote populations (Bank Indonesia, 2014).

Over the last few decades, financial inclusion has become a substantial topic in many countries. As many as 38\% of the world's adults have not accessed or used formal financial services, even $73 \%$ of poor people do not have bank accounts due to costs, travel distance to nearby financial institutions, and often burdensome terms in opening financial accounts. Over the last few decades, there have been many efforts carried out by national institutions to improve the inclusive society's finances by offering financial services that are easily accessible to the community and working with other institutions. These institutions include non-governmental organizations, cooperatives, community-based development agencies, commercial and government banks, insurance companies and credit card, telecommunications, post office, and other business service providers. These institutions provide various service points or point-of-sales as new business models. However, this new service can utilize only if a person has a deposit account (Collins et al., 2009; Demombynes \& Thegeya, 2012; Ouma et al., 2017; Shem et al., 2012).

Also, Indonesia has formulated a strategy to increase financial inclusion since 2012 (Bank Indonesia, 2014). However, the evaluation indicated that the Inclusive Financial Index of Indonesia was still low. The Indonesian Inclusive Financial Index over the age of 15 reached 36.1 (World Bank, 2014). This data means that only about 36.1\% of Indonesian people accessed and used savings products in formal financial institutions which in this case is the bank. Compared to the level of financial inclusion with ASEAN countries, Indonesia's position is still far below Singapore, Malaysia, and Thailand. The low Indonesian Inclusive Financial Index was thought to be influenced by price barrier, information barrier, product and service design barriers, channel and distribution. Therefore, in this study, we investigate the factors that affect financial inclusion in Indonesia.

There are several works of literature discussing factors influencing access and use of financial services (Aterido et al., 2013; Fungáčová \& Weill, 2014; Ghosh \& Vinod, 2017; Kostov et al., 2015; Ouma et al., 2017; Zins \& Weill, 2016). Previous evidence proved that access and use of the services of formal financial institutions had contributed positively to economic growth and social development on both individual and corporate scale (Chauvet \& Jacolin, 2017; Han et al., 2013; Kim et al., 2018; World Bank, 2014). 
There are two critical terms in analyzing financial inclusion. The first is access to financial institutions. A person who does not have access to a financial institution can attribute to cost constraints, regulated financial institutions, law, or culture. While someone who does not use financial services can already have access but based on his own choice, choose not to use such financial services (World Bank, 2014). The lack of access and use of the services of formal financial institutions has a significant impact on poverty, inequality, unemployment, unsustainable development (Galor \& Zeira, 1993; Ghosh \& Vinod, 2017; Menon \& van der Meulen, 2011; Swamy, 2014; World Bank, 2014). Moreover, access and use to formal financial institutions can reduce child labor, improve economic efficiency and living standards of society (Becker, 1975; Chakravarty \& Pal, 2013; Conroy, 2005).

There are several indicators used to analyze financial inclusion based on works of literature. Some of these indicators are the availability of financial products, the adoption of products, the use of products, and the importance of the product. Availability of financial products measures the availability of institutions, products, and financial services, particularly banking for the community. This indicator measure from the supply side - the adoption of products measures ownership of bank accounts by individuals and companies. Use of products measures the degree of frequency of consumers in using financial products or services over some time, through saving or accessing the loan. Finally, the importance of the product measures the financial institution's product capability in meeting consumer needs (Arun \& Kamath, 2015; Zins \& Weill, 2016).

The four indicators then differentiate into indicators of access and use of financial products or services. The availability of financial products and the adoption of products are used to measure public access to financial institutions. However, technological developments in the digital age today lead the adoption of products considered to be the primary indicator of access to financial institutions. This indicator is because the availability of financial products consider as a physical form of financial institutions, and at present, the digital form of financial institutions has widely introduced. Suppose in Indonesia has been introduced digital financial services program through LKD and LAKU PANDAI (Bank Indonesia, 2013). Thus, someone who has an account with a bank is considered to have access to a financial institution. Thus, the other two indicators, namely the use of products and the importance of the products are considered an indicator of the use of products or services of financial institutions (Arun \& Kamath, 2015).

Previous findings proved that some individual characteristics are associated with financial inclusion indicators (Zins \& Weill, 2016). Those characteristics include gender, education, income, location of residence, occupation, and marital status (Allen, et al., 2016; Anzoategui et al., 2014; Aterido et al., 2013; Fungáčová \& Weill, 2014; Zins \& Weill, 2016). Moreover, household size, age, and remittances are also proven to affect financial inclusion (Anzoategui et al., 2014). Based on the literature reviews and the result of previous empirical studies, we propose the relationship analysis of the gender, education level, age, income level, and type of work.

This study contributes to the literature as a depth analysis of financial inclusion determinants in Indonesia. Prior studies that discussed similar issues in Indonesia had conducted in the scope of smaller areas such as Wardhono et al., (2016) that examined the 
factors that influence financial inclusion in Bondowoso and Jember Regency. Moreover, the scope of financial inclusion carried out is limited to the utilization of banking products. Likewise, Trinugroho et al., (2015) examined the determinants of financial deepening in Indonesia but were limited to country-level data and macro variables such as regional gross domestic products and the number of bank branches per province. Sun (2015) also conducted a similar analysis, but the study focused on micro enterprises with revenue less than 300 million/year.. Another research by Santoso et al., (2016) that compared the levels of financial inclusion and financial literacy between rural and urban households.

This study employs broader indicators of financial inclusion, ownership of formal financial institutions, saving at formal institutions and borrowing from formal financial institutions. Besides, we use the individual-level data that are individuals aged 15 years and above. This study also provides an analysis of critical issues regarding loan sources for the poor and its determinants that have not been covered by previous studies. The findings of this study will be expected to contribute as a principle for the formulation of the government and formal financial institutions.

\section{Methods}

The data used in this study was Global Financial Inclusion (Global Findex) data for Indonesia 2014. Global findex was data released by the World Bank collected through survey techniques covering 150,000 samples in more than 140 countries. For Indonesia, this data covered as many as 1000 samples aged 15 years and over. Data collection was carried out by using a stratified random sampling method. Financial inclusion indicators used in this study were: (1) ownership of accounts in formal financial institutions; (2) saving in formal financial institutions; and (3) borrowing from formal financial institutions (Zins \& Weill, 2016).

In this study, binary logistic regression was carried out to test the above hypotheses because the dependent variable has a nominal scale. The estimation model used followed Zins \& Weill (2016) with the following formulation:

$$
P(\mathrm{Y}=1)=\frac{1}{1+\exp \left(-\left(\beta 0+\beta 1 \mathrm{Gen}_{i}+\beta 2 \operatorname{Age}_{i}+\beta 3 \operatorname{Inc}_{i}+\beta 4 \operatorname{Edu}_{i}+\beta 5 \operatorname{Priv}_{i}+\beta 6 \operatorname{Pub}_{i}+\beta 6 \operatorname{Agr}_{i}\right)\right.}
$$

Where $\mathrm{Y}$ is an indicator of financial inclusion and financial inclusion barriers. Variable Gen $=$ gender, Age = age, $\mathrm{Inc}=$ income, $\mathrm{Edu}=$ education, Priv = private sector, $\mathrm{Pub}=$ public sector, and Agr = agriculture sector. Gender, income, education, private sector, public sector, and agriculture sector are nominal and ordinal scale dummy variables. While the variable age is a variable scale.

The goodness of fit of the model evaluated through the Hosmer-Lemeshow test, and the probability of each variable is evaluated using a pseudo R square (Hosmer Jr \& Lemeshow, 2000; Ramos et al., 2017).

\section{Result and Discussion}

The results of the descriptive analysis in Table 1 shows that the financial inclusion in Indonesia is lower than the benchmark countries, namely Malaysia, Singapore, and Thailand. A total of $39.7 \%$ of Indonesians has accounts in formal financial institutions. While in 
Singapore $95.6 \%$ of the population has accounts at formal financial institutions. The facts in Malaysia and Thailand are also still high, namely $83.4 \%$ and $78.8 \%$. Similar evidence also applied to save and lending activities. The average percentage of Indonesia is lower than the benchmark countries. This condition illustrated that access and use of financial institution services in Indonesia are still low.

Table 1. Descriptive Statistics Results

\begin{tabular}{|c|c|c|c|c|c|c|}
\hline \multirow{2}{*}{ Variables } & \multirow{2}{*}{$\begin{array}{l}\text { Number } \\
\text { of Obs. }\end{array}$} & \multirow{2}{*}{ Mean } & \multirow{2}{*}{$\begin{array}{l}\text { Std. } \\
\text { Deviation }\end{array}$} & \multicolumn{3}{|c|}{ Mean of Benchmark countries } \\
\hline & & & & Malaysia & Singapore & Thaiand \\
\hline \multicolumn{7}{|l|}{ Financial Inclusion } \\
\hline $\begin{array}{l}\text { Ownership of accounts in formal } \\
\text { financial institutions }\end{array}$ & 1000 & .397 & .490 & .834 & .956 & .788 \\
\hline $\begin{array}{l}\text { Saving in formal financial } \\
\text { institutions }\end{array}$ & 385 & .838 & .396 & .756 & .867 & .915 \\
\hline $\begin{array}{l}\text { Borrowing from formal financial } \\
\text { institutions }\end{array}$ & 992 & .064 & .286 & .212 & .312 & .105 \\
\hline \multicolumn{7}{|l|}{ Constraints to access } \\
\hline Too far away & 612 & .302 & .513 & .338 & .940 & 240 \\
\hline Too expensive & 612 & .227 & .557 & .423 & .132 & .122 \\
\hline Lack of documentation & 612 & .204 & .462 & .296 & .208 & .077 \\
\hline Lack of trust & 612 & .072 & .342 & .216 & .113 & .045 \\
\hline Religious reason & 612 & .042 & .271 & .108 & .113 & .018 \\
\hline Lack of money & 612 & .665 & .532 & .615 & .340 & .335 \\
\hline Family member already has one & 612 & .222 & .506 & .479 & .377 & .484 \\
\hline Cannot get one & 612 & .253 & .505 & .268 & .094 & .104 \\
\hline No need for financial services & 612 & .335 & .541 & .554 & .283 & .353 \\
\hline \multicolumn{7}{|l|}{ Saving motivation } \\
\hline For farming/business & 990 & .253 & .452 & .196 & .113 & .168 \\
\hline For old age & 993 & .314 & .476 & .580 & .485 & .645 \\
\hline For education & 993 & .389 & .500 & .506 & .323 & .216 \\
\hline \multicolumn{7}{|l|}{ Loan motivation } \\
\hline For education & 998 & .132 & .347 & .124 & .032 & .070 \\
\hline For medical purposes & 998 & .174 & .383 & .074 & .029 & .201 \\
\hline For farming/business & 1000 & .128 & .334 & .076 & .015 & .131 \\
\hline \multicolumn{7}{|l|}{ Loan source } \\
\hline Financial institution & 994 & .144 & .371 & .214 & .134 & .152 \\
\hline Store & 994 & .070 & .268 & .133 & .067 & .025 \\
\hline Family or friends & 994 & .405 & .502 & .405 & .052 & .293 \\
\hline Private lender & 994 & .032 & .193 & .009 & .011 & .095 \\
\hline
\end{tabular}

Furthermore, the main factor that prevents individuals from accessing financial services is lack of money about $66.5 \%$ (See Table 1). This finding is consistent with the results of Zins $\&$ Weill (2016). Since the same variables applied in Malaysia, Singapore and Thailand are 
different. Too far away is a significant factor in Singapore while the family member already has one becomes the main obstacle factor.

Moreover, the main motivations that influence consumer decisions to save in financial institutions are for educational needs (38.9\%) and followed by the needs in old age (31.4\%). This finding is relevant to Allen et al., (2016), and Zins \& Weill (2016). The same applies to the benchmark countries. While the motivations take a loan is for medical purposes (17.4\%), for educational purposes (13.2\%) and farming/business purposes (12.8\%). The same applies to Malaysia. However, in Singapore, the majority of loan is used for education, and in Thailand for farming/business. Finally, the majority of financing sources in Indonesia source from families and friends (40.5\%). Loans from formal financial institutions only amounted to $14.4 \%$. The same conditions also apply in Malaysia and Thailand, but with a lower percentage. While in Singapore, the majority of loan sources come from formal financial institutions. These findings are also relevant to Zins \& Weill (2016).

Table 2. Determinants of Financial Inclusion in Indonesia

\begin{tabular}{lccc}
\hline \multicolumn{1}{c}{ Individual indicators } & $\begin{array}{c}\text { Ownership of accounts } \\
\text { in formal financial } \\
\text { institutions (Exp (B)) }\end{array}$ & $\begin{array}{c}\text { Saving in formal } \\
\text { financial institutions } \\
\text { (Exp (B)) }\end{array}$ & $\begin{array}{c}\text { Borrowing from } \\
\text { formal financial } \\
\text { institutions (Exp (B)) }\end{array}$ \\
\hline Gender & $1.570^{* *}$ & 1.621 & .605 \\
Age & .996 & .986 & $.954^{* *}$ \\
Income (poorest 20\%) & $3.946^{* * *}$ & 2.030 & .5096 \\
Income (second 20\%) & $2.797^{* * *}$ & 1.254 & 1.520 \\
Income (third 20\%) & $2.064^{* * *}$ & .959 & 1.859 \\
Income (fourth 20\%) & $1.706^{* *}$ & 1.148 & $2.751^{* *}$ \\
Education (completed primary & .000 & $15.758^{* * *}$ & .000 \\
or less) & .000 & 2.979 & .000 \\
Education (secondary) & .000 & - & .000 \\
Education (completed tertiary & 1.935 & 3.32 & .000 \\
or more) & 1.414 & .417 & .4 .754 \\
Work in private sector & .000 & .065 & .000 \\
Work in public sector & 1000 & 385 & 992 \\
Work in agriculture sector & .311 & .192 & .171 \\
Observations & 1049.873 & 290.156 & 362.973 \\
Nagelkerke R & 72.3 & 82.3 & 94.5 \\
Log likelihood & $5 \%$ & & \\
Overall percentage & & & \\
\hline
\end{tabular}

${ }^{*}$ Significance at the $10 \%$ level. ${ }^{* *}$ Significance at the $5 \%$ level. ${ }^{* * *}$ Significance at the $1 \%$ level.

From the data analysis in Table 2, we find that some of the individual characteristics are related to financial inclusion. First, gender has a significant positive effect on account ownership at formal financial institutions. Men have 1.570 more likely to have accounts in formal financial institutions than women. These results are consistent with Fungáčová \& Weill (2014), and Zins \& Weill (2016). Then, increased income will further increase the likelihood of ownership of accounts in formal financial institutions. This finding is consistent 
with Allen et al., (2016). In terms of the use of financial services, variables affecting savings activities in formal financial institutions are only the primary education variables (completed primary or less). This finding is different from previous research by Zins \& Weill (2016). Odd of educated individuals completed primary or less is by 15,758 times compared to individuals from other educational levels. Finally, the variables that affect borrowing from formal financial institutions are age and income. Increased age and income will lead to the likelihood of having a loan. This result is because high-income groups are more likely to have collateral in applying for loans. It concludes that education, age, and income are the variables that influence the use of financial services in Indonesia.

Table 3. Determinants of Constraints to Financial Inclusion in Indonesia

\begin{tabular}{|c|c|c|c|c|c|c|c|c|c|}
\hline Indicators & $\begin{array}{l}\text { Too far } \\
\text { away } \\
(\exp (\mathrm{B}))\end{array}$ & $\begin{array}{c}\text { Too } \\
\text { expensive }\end{array}$ & $\begin{array}{c}\text { Lack of } \\
\text { documentation }\end{array}$ & $\begin{array}{l}\text { Lack of } \\
\text { trust }\end{array}$ & $\begin{array}{l}\text { Lack of } \\
\text { money }\end{array}$ & $\begin{array}{l}\text { Religious } \\
\text { reasons }\end{array}$ & $\begin{array}{c}\text { Family } \\
\text { member } \\
\text { already has } \\
\text { one }\end{array}$ & $\begin{array}{c}\text { Can't get } \\
\text { one }\end{array}$ & $\begin{array}{c}\text { No } \\
\text { need for } \\
\text { financial } \\
\text { services }\end{array}$ \\
\hline Gender & .967 & 1.212 & .883 & 1.005 & .895 & 1.605 & .754 & 1.306 & 1.553 \\
\hline Age & 1.009 & 1.005 & $1.032^{* * *}$ & .998 & 1.003 & .976 & 1.005 & 1.011 & .981 \\
\hline $\begin{array}{l}\text { Income } \\
\text { (poorest } 20 \% \text { ) }\end{array}$ & $.314^{* * *}$ & $.328^{* *}$ & .792 & $.254^{*}$ & $.278^{* * *}$ & 1.342 & $2.038^{* *}$ & $.409^{* *}$ & .795 \\
\hline $\begin{array}{l}\text { Income } \\
\text { (second 20\%) }\end{array}$ & $.520^{*}$ & $.389 * * *$ & .703 & .299 & $.272^{* * *}$ & 1.413 & $4.934^{* * *}$ & $.401^{* * *}$ & 1.191 \\
\hline $\begin{array}{l}\text { Income (third } \\
20 \% \text { ) }\end{array}$ & $.548^{*}$ & .711 & .642 & .378 & $.412^{* *}$ & .913 & $1.723^{*}$ & $.419^{* *}$ & .642 \\
\hline $\begin{array}{l}\text { Income } \\
\text { (fourth } 20 \% \text { ) }\end{array}$ & .837 & 1.029 & 1.217 & .305 & $.552^{*}$ & .958 & 1.298 & .967 & 1.064 \\
\hline $\begin{array}{l}\text { Education } \\
\text { (primary or } \\
\text { less) }\end{array}$ & .000 & .000 & .000 & .000 & 1.169E8 & .000 & .000 & .000 & .000 \\
\hline $\begin{array}{l}\text { Education } \\
\text { (secondary) }\end{array}$ & .000 & .000 & .000 & .000 & $1.665 \mathrm{E} 8$ & .000 & .000 & .000 & .000 \\
\hline $\begin{array}{l}\text { Education } \\
\text { (tertiary or } \\
\text { more) }\end{array}$ & .000 & .000 & .000 & .000 & $1.775 \mathrm{E} 8$ & .000 & 2.810 & .000 & .000 \\
\hline $\begin{array}{l}\text { Work in } \\
\text { private sector }\end{array}$ & 1.814 & .000 & $1.051 \mathrm{E} 10$ & 5.998 & .810 & .000 & .000 & .000 & .000 \\
\hline $\begin{array}{l}\text { Work in public } \\
\text { sector }\end{array}$ & $3.990^{*}$ & $4.192^{*}$ & 2.477 & 8.559 & .196 & 2.537 & 1.470 & 3.694 & 1.378 \\
\hline $\begin{array}{l}\text { Work in } \\
\text { agriculture } \\
\text { sector }\end{array}$ & .000 & 1.773.E10 & $3.253 \mathrm{E} 10$ & .000 & .000 & $1.446 \mathrm{E} 10$ & .000 & 2.297E10 & .000 \\
\hline Obs. & 594 & 554 & 592 & 587 & 598 & 596 & 578 & 587 & 586 \\
\hline Nagelkerke $\mathrm{R}^{2}$ & .070 & .123 & .111 & .115 & .143 & .159 & .152 & .109 & .076 \\
\hline Log likelihood & 754.985 & 614.362 & 642.434 & 280.898 & 689.426 & 159.843 & 606.275 & 685.728 & 740.042 \\
\hline Overall \% & 69.6 & 75.1 & 76.9 & 93.3 & 73.4 & 96.7 & 76.6 & 72.6 & 69.5 \\
\hline
\end{tabular}

*Significance at the $10 \%$ level. ${ }^{* *}$ Significance at the $5 \%$ level. ${ }^{* * *}$ Significance at the $1 \%$ level

The next discussion is individual characteristics that affect individuals not having accounts in formal financial institutions. This analysis is critical to determine whether these barriers are voluntary constraints or involuntary constraints (Allen et al., 2016). Gender has nothing to do with account ownership restrictions at formal financial institutions. Ageassociated with lack of documentation barriers. Income is related to the obstacles too far 
away, too expensive, lack of trust, lack of money, family member already has one, and can not get one. According to Zins \& Weill (2016), all of these factors become an obstacle, especially for low-income individuals. This phenomena also evidenced in the findings in this study, where the population at the higher $20 \%$ income level has no relationship with the above barriers except the lack of money. Furthermore, the education and employment sectors have no relationship at all with financial inclusion barriers. This finding is different with Allen et al., (2016), Fungáčová \& Weill (2014), and Zins \& Weill, 2016); where education and occupation affect barriers to accessing financial institutions. (For details shows in Table 3).

Table 4. Determinants of Financial Services Utilization

\begin{tabular}{|c|c|c|c|c|c|c|}
\hline \multirow[b]{2}{*}{ Indicators } & \multicolumn{3}{|c|}{ Saving motivation } & \multicolumn{3}{|c|}{ Borrowing motivation } \\
\hline & $\begin{array}{l}\text { For farming/ } \\
\text { business }\end{array}$ & $\begin{array}{l}\text { For old } \\
\text { age }\end{array}$ & $\begin{array}{c}\text { For } \\
\text { education }\end{array}$ & $\begin{array}{l}\text { For farming/ } \\
\text { business }\end{array}$ & $\begin{array}{l}\text { For health/ } \\
\text { medicine }\end{array}$ & $\begin{array}{c}\text { For } \\
\text { education }\end{array}$ \\
\hline Gender & $.708^{* *}$ & 1.287 & $1.312^{*}$ & 1.176 & 1.287 & 1.356 \\
\hline Age & $.987^{* *}$ & $.971^{* * *}$ & .991 & .989 & $.981^{* *}$ & .994 \\
\hline Income (poorest $20 \%$ ) & $2.682^{* * *}$ & $2.34^{* * *}$ & $1.965^{*}$ & $2.531^{* * * *}$ & .880 & $1.890^{* * *}$ \\
\hline Income (second $20 \%$ ) & $2.298^{* *}$ & $2.28^{* * *}$ & $1.676^{* *}$ & $1.727^{*}$ & .727 & $1.890^{* * *}$ \\
\hline Income (third $20 \%$ ) & 1.459 & 1.389 & 1.205 & 1.557 & .762 & $.387^{* *}$ \\
\hline Income (fourth $20 \%$ ) & 1.426 & 1.135 & 1.304 & 1.558 & 1.514 & .644 \\
\hline $\begin{array}{l}\text { Income } \\
\text { (primary or less) }\end{array}$ & .000 & .000 & .000 & .000 & $1.585 \mathrm{E} 9$ & .000 \\
\hline Education (secondary) & .000 & .000 & .000 & .000 & $1.112 \mathrm{E} 9$ & .000 \\
\hline $\begin{array}{l}\text { Education (tertiary or } \\
\text { more) }\end{array}$ & .000 & .000 & .000 & .000 & $1.089 \mathrm{E} 9$ & .000 \\
\hline Work in private sector & 1.157 & 1.282 & .677 & 1.374 & 3.535 & 2.200 \\
\hline Work in public sector & 1.944 & 1.343 & .454 & 1.408 & .318 & .667 \\
\hline $\begin{array}{l}\text { Work in agriculture } \\
\text { sector }\end{array}$ & .000 & $6.81 \mathrm{E} 8$ & $1.078 \mathrm{E} 9$ & 3.353E9 & .000 & $1.68 \mathrm{E} 10$ \\
\hline Observations & 990 & 993 & 993 & 1000 & 998 & 998 \\
\hline Nagelkerke $\mathrm{R}^{2}$ & .166 & .170 & .168 & .115 & .146 & .165 \\
\hline Log likelihood & 949.876 & 1039.56 & 1139.493 & 661.145 & 783.524 & 650.550 \\
\hline Overall percentage & 77.7 & 75.0 & 69.3 & 88.4 & 84.4 & 87.9 \\
\hline
\end{tabular}

*Significance at the $10 \%$ level. ${ }^{* *}$ Significance at the $5 \%$ level. ${ }^{* *}$ Significance at the $1 \%$ level

We regress the individual characteristics with saving and loan motivation of individuals. The results show in Table 4. In general, individual motivation differences for saving influenced by gender, age, and income factors. Gender variables have a positive influence on saving motivation for farming/business and education. Males have a higher odds ratio than females, which is 0.708 times in farming/business motivation and 1.312 times higher in educational motivation. This finding is relevant to the previous literature by Zins \& Weill (2016). This result can be an indication that men dominate decision making in farming/business and educational activities.

The income level also has a significant effect on the saving motivation of the individual. The saving motivations for both farming/business, old age, and educational purposes are 
lower in line with rising income levels (See Table 4). The primary motivation of lowincome individuals (20\% lower and second 20\%) saving in formal financial institutions is more due to the purpose of farming/business compared to other objectives. Moreover, the age of the individual affects the motivation of individuals to save for farming/business and old age. However, age is not related to individual motivation for educational purposes. This finding contradicts Zins \& Weill (2016), where it mentioned that age is related to the motivation of saving for education. This difference may be due to the demographic structure of Indonesia that the higher the age of a person, the importance of saving for the business.

Table 5. Determinants of Loan Sources

\begin{tabular}{|c|c|c|c|c|}
\hline Indicators & $\begin{array}{c}\text { Financial institution } \\
(\exp (B))\end{array}$ & Store $(\exp (B))$ & $\begin{array}{l}\text { Family or friend } \\
\qquad(\exp (B))\end{array}$ & $\begin{array}{c}\text { Private lender } \\
(\exp (\mathrm{B}))\end{array}$ \\
\hline Gender & .907 & .967 & 1.108 & $2.023^{*}$ \\
\hline Age & $.971 * * *$ & 1.003 & $1.016^{* *}$ & .979 \\
\hline Income (poorest $20 \%$ ) & $2.639^{*}$ & $2.961^{* *}$ & 1.038 & .510 \\
\hline Income (second $20 \%$ ) & .924 & 1.202 & .771 & .657 \\
\hline Income (third $20 \%$ ) & 1.160 & $2.823^{*}$ & .851 & .632 \\
\hline Income (fourth $20 \%$ ) & 1.649 & $3.057 * * *$ & 1.305 & 1.798 \\
\hline $\begin{array}{l}\text { Income (completed } \\
\text { primary or less) }\end{array}$ & .000 & .000 & 3.087E8 & .000 \\
\hline Education (secondary) & .000 & .000 & $2.528 \mathrm{E} 8$ & .000 \\
\hline $\begin{array}{l}\text { Education (completed } \\
\text { tertiary or more) }\end{array}$ & .000 & .000 & $4.272 \mathrm{E} 8$ & .000 \\
\hline Work in private sector & .000 & .956 & .000 & 3.739 \\
\hline Work in public sector & $2.972^{*}$ & 2.755 & .433 & 3.472 \\
\hline $\begin{array}{l}\text { Work in agriculture } \\
\text { sector }\end{array}$ & 3.930E9 & .000 & 4.105E9 & .000 \\
\hline Observations & 994 & 994 & 994 & 994 \\
\hline Nagelkerke $\mathrm{R}^{2}$ & .108 & .100 & .150 & .122 \\
\hline Log likelihood & 716.086 & 458.882 & 1232.336 & 236.082 \\
\hline Overall percentage & 87.1 & 93.0 & 65.9 & 97.2 \\
\hline
\end{tabular}

${ }^{*}$ Significance at the $10 \%$ level. ${ }^{* *}$ Significance at the $5 \%$ level. ${ }^{* * *}$ Significance at the $1 \%$ level

Furthermore, the variables that affect the difference in loan motivation are age and income. Age affects loan motivation for medical purposes. This finding can understand as an increase in age will increase the likelihood of developing illness and thus increase the motivation to apply for a loan to a formal financial institution. Then small-income individuals (most deprived 20\%, second 20\%) and medium (third 20\%) influence the possibility of applying for loans to formal financial institutions for educational needs. However, this possibility decreases with increasing income levels. This result is because low-income individuals need more loans because of limited savings than individuals from high-income groups. This result differs from Zins \& Weill (2016) which stated that individuals from the lowest income group have no formal relationship to the motivation to apply for loans for 
educational needs. Moreover, the variables of education, gender, occupation are not related to individual motivation differences in saving and applying for a loan.

The further result in Table 5 indicated that gender, age, income and type of jobs are the variables that affected the loan sources. Men have a higher chance to borrow on private lenders. This finding matches with Zins \& Weill (2016). Later age is related to the source of the loan is coming from financial institution and family or friend. This result means that the higher the age of increasing the chances of someone is getting a loan from both sources. The opportunity to get a loan from family or friend is more significant than a financial institution. Individuals from low-income groups tend to borrow from financial institutions and store. This finding is surprising given the results of previous studies by Zins \& Weill (2016) highincome individuals are more likely to get loans from financial institutions. Then the type of work in the public sector has a higher chance to get a loan from a financial institution. Finally, education in this study does not affect the source of individual loans.

\section{Conclusion}

Generally, the result of this study indicates that the average financial inclusion in Indonesia is lower than benchmark countries, namely Malaysia, Singapore, and Thailand. Individual characteristics that affect financial inclusion are gender, age, income, and education. The main factor that prevents individuals from accessing financial services is lack of money. Furthermore, the main motivations that influence consumer decisions to save in financial institutions are for educational needs and the needs in old age. Individual characteristics that affect inclusive finance are gender, age, income, and education. While the difference in barriers to financial inclusion caused by age and education. Finally, the difference in motivation in utilizing financial services and loan sources is affected by gender, age, and income differences.

Overall, the results of this study support and relevant to previous literature. Although there are several different facts, this distinction is interesting to discuss in future research which covers the influence of income, age, education, job sector to the source of loans, motivation to apply for a loan for education needs, and saving motivation for education. Also, the limitations of this study are the data utilizing were limited to the cross-sectional data in 2014. For future research can be considered to use the updated data in 2017 or time series data from each year published findex survey reported in order to be able to observe the development of each indicator financial inclusion and changes in individual characteristics across the year.

\section{References}

Allen, F., Demirguc-Kunt, A., Klapper, L., \& Martinez Peria, M. S. (2016). The Foundations of Financial Inclusion: Understanding Ownership and Use of Formal Accounts. Journal of Financial Intermediation, 27(2016), 1-30. https://doi.org/10.1016/j.jfi.2015.12.003.

Anzoategui, D., Demirgüç-Kunt, A., \& Martínez Pería, M. S. (2014). Remittances and Financial Inclusion: Evidence from El Salvador. World Development, 54, 338-349. https://doi. org/10.1016/j.worlddev.2013.10.006. 
Arun, T., \& Kamath, R. (2015). Financial inclusion: Policies and practices. IIMB Management Review, 27(4), 267-287. https://doi.org/10.1016/j.iimb.2015.09.004.

Aterido, R., Beck, T., \& Iacovone, L. (2013). Access to Finance in Sub-Saharan Africa: Is There a Gender Gap? World Development, 47, 102-120. https://oi.org/10.1016/j. worlddev.2013.02.013.

Bank Indonesia. (2014). Booklet Keuangan Inklusif. Departemen Pengembangan Akses Keuangan dan UMKM. Retrieved July 27, 2017, from http://www.bi.go.id/id/ perbankan/keuanganinklusif/edukasi/Contents/Buku Saku Keuangan Inklusif.pdf.

Becker, G. S. (1975). Human capital. New York: Columbia University Press.

Chakravarty, S. R., \& Pal, R. (2013). Financial Inclusion in India: An Axiomatic Approach. Journal of Policy Modeling, 35(5), 813-837. https://doi.org/10.1016/j.jpolmod.2012.12.007.

Chauvet, L., \& Jacolin, L. (2017). Financial Inclusion, Bank Concentration, and Firm Performance. World Development, 97, 1-13. https://doi.org/10.1016/j.worlddev.2017.03.018.

Claessens, S. (2006). Access to Financial Services: A Review of the Issues and Public Policy Objectives. World Bank Research Observer, 21(2), 207-240. https://doi.org/10.1093/ wbro/lkl004.

Collins, D., Morduch, J., Rutherford, S., Ruthven, O. (2009). Portfolios of the Poor: How The World's Poor Live on \$2 a Day. Princeton, NJ.: Princeton University Press.

Conroy, J. (2005). APEC and Financial Exclusion: Missed Opportunities for Collective Action? Asia Pacific Development Journal, 12(1), 53-80. https://doi.org/10.1017/ CBO9781107415324.004.

Demombynes, G., \& Thegeya, A. (2012). Kenya's Mobile Revolution and the Promise of Mobile Savings. World Bank Policy Research Working Paper No. 12/5988, 5988(1), 32. https://doi.org/doi:10.1596/1813-9450-5988.

Fungáčová, Z., \& Weill, L. (2014). Understanding Financial Inclusion in China. China Economic Review, 34, 196-206. https://doi.org/10.1016/j.chieco.2014.12.004.

Galor, O., \& Zeira, J. (1993). Income Distribution Macroeconomics. Review of Economic Studies, 60(1), 35-52. https://doi.org/10.2307/2297811.

Ghosh, S., \& Vinod, D. (2017). What Constrains Financial Inclusion for Women? Evidence from Indian Micro data. World Development, 92, 60-81. https://doi.org/10.1016/j. worlddev.2016.11.011.

Global Partnership for Financial Inclusion. (2011). G20 principles for innovative financial inclusion. Alliance for Financial Inclusion Bangkok Thailand. Retrieved July 27, 2017, from https://www.gpfi.org/sites/default/files/documents/G20 Principles for Innovative Financial Inclusion - AFI brochure.pdf

Han, R., Melecky, M., \& Bank, W. (2013). MPRA Paper No. 48338, posted 19, (48338), 58. Retrieved from http://mpra.ub.uni-muenchen.de/48338/

Hosmer Jr, D. W., \& Lemeshow, S. (2000). Applied Logistic Regression (2 ${ }^{\text {nd }}$ ed). New York: John Wiley \& Sons. 
Kim, D. W., Yu, J. S., \& Hassan, M. K. (2018). Financial Inclusion and Economic Growth in OIC Countries. Research in International Business and Finance, 43, 1-14. https://doi. org/10.1016/j.ribaf.2017.07.178

Kostov, P., Arun, T., \& Annim, S. (2015). Access to Financial Services: The Case of the "Mzansi" Account in South Africa. Review of Development Finance, 5(1), 34-42. https:// doi.org/10.1016/j.rdf.2015.04.001

Menon, N., \& van der Meulen, Y. (2011). How Access to Credit Affects Self Employment: Differences by Gender During India's Rural Banking Reform. Journal of Development Studies, 47(1), 48-69. https://doi.org/10.1080/00220381003706486

Ouma, S. A., Odongo, T. M., \& Were, M. (2017). Mobile Financial Services and Financial Inclusion: Is it a Boon for Savings Mobilization? Review of Development Finance, 7(1), 29-35. https://doi.org/10.1016/j.rdf.2017.01.001

Ramos, J. G. R., Teles Correa, M. D., de Carvalho, R. T., Jones, D., \& Forte, D. N. (2017). Clinical Significance of Palliative Care Assessment in Patients Referred for Urgent Intensive Care Unit Admission: A Cohort Study. Journal of Critical Care, 37, $24-29$. https://doi.org/10.1016/j.jcrc.2016.08.018

Santoso, A. B., Trinugroho, I., Nugroho, L. I., Saputro, N., \& Purnama, M. Y. I. (2016). Determinants of Financial Literacy and Financial Inclusion Disparity within a Region: Evidence from Indonesia. Advanced Science Letters, 22(5-6), 1622-1624.

Shem, A. O., Misati, R., \& Njoroge, L. (2012). Factors Driving Usage of Financial Services From Different Financial Access Strands in Kenya. Savings and Development, 36(1), 7189. https://doi.org/10.2307/savideve.36.1.71

Sun Y. (2015). Financial Inclusion: Study from Indonesia. Advanced Science Letters, 21(4), 1039-1043.

Swamy, V. (2014). Financial Inclusion, Gender Dimension, and Economic Impact on Poor Households. World Development, 56, 1-15. https://doi.org/10.1016/j.worlddev.2013.10.019

Trinugroho, I., Agusman, A., Ariefianto, M. D., Darsono, D., \& Tarazi, A. (2015). Determinants of Cross Regional Disparity in Financial Deepening: Evidence From Indonesian Provinces. Economics Bulletin, 35(2), 896-910.

Wardhono, A., Qori'Ah, C. G., \& Indrawati, Y. (2016). The Determinants of Financial Inclusion: Evidence from Indonesian Districts. International Journal of Economic Perspectives, 10(4), 472-483.

World Bank. (2014). Global Financial Development Report 2014: Financial Inclusion. Washington, DC: World Bank.

Zins, A., \& Weill, L. (2016). The Determinants of Financial Inclusion in Africa. Review of Development Finance, 6(1), 46-57. https://doi.org/10.1016/j.rdf.2016.05.001 